This is the author's final, peer-reviewed manuscript as accepted for publication. The publisher-formatted version may be available through the publisher's web site or your institution's library.

\title{
Dedicated bioenergy crop impacts on soil wind erodibility and organic carbon in Kansas
}

Byron J. Evers, Humberto Blanco-Canqui, Scott Staggenborg, and John Tatarko

\section{How to cite this manuscript}

If you make reference to this version of the manuscript, use the following information:

Evers, B. J., Blanco-Canqui, H., Staggenborg, S., \& Tatarko, J. (2013). Dedicated bioenergy crop impacts on soil wind erodibility and organic carbon in Kansas. Retrieved from http://krex.ksu.edu

\section{Published Version Information}

Citation: Evers, B. J., Blanco-Canqui, H., Staggenborg, S., \& Tatarko, J. (2013). Dedicated bioenergy crop impacts on soil wind erodibility and organic carbon in Kansas. Agronomy Journal, 105(5), 1271-1276.

Copyright: Copyright $@ 2013$ by the American Society of Agronomy

Digital Object Identifier (DOI): doi:10.2134/agronj2013.0072

Publisher's Link: https://www.agronomy.org/publications/aj/articles/105/5/1271

This item was retrieved from the K-State Research Exchange (K-REx), the institutional repository of Kansas State University. K-REx is available at http://krex.ksu.edu 


\section{Dedicated Bioenergy Crop Impacts on Soil Wind Erodibility and Organic Carbon in Kansas}

3

4 Byron J. Evers ${ }^{1}$, Humberto Blanco-Canqui ${ }^{2}$, Scott Staggenborg ${ }^{1}$, and John Tatarko ${ }^{3}$ 5

6

7 'Kansas State University, Department of Agronomy. 2004 Throckmorton Plant Sciences Center,

8 Manhattan, KS 66506

9

10 'University of Nebraska, Department of Agronomy and Horticulture, 261 Plant Science Hall, 11 Lincoln, NE 68583

$12 *$ Corresponding author (hblancocanqui2@unl.edu)

13

$14{ }^{3}$ John Tatarko, USDA, Engineering \& Wind Erosion Research Unit, Manhattan, KS

15 


\section{ABSTRACT}

17 Dedicated bioenergy crops such as perennial warm-season grasses (WSGs) may reduce soil

18 erosion and improve soil properties while providing biomass feedstock for biofuel. We

19 quantified impacts of perennial WSGs and row crops on soil wind erodibility parameters

20 (erodible fraction, geometric mean diameter of dry aggregates, and aggregate stability) and soil

21 organic carbon (SOC) concentration under a dedicated bioenergy crop experiment in eastern

22 Kansas after 4 and 5 yr of management. Soil properties were measured under switchgrass

23 (Panicum virgatum L.), big bluestem (Andropogon gerardii L.), miscanthus (Miscanthus $\times$

24 giganteus), and annual row crops including continuous corn (Zea mays L.), photoperiod sorghum

25 (Sorghum bicolor L. [Moench.]), sweet sorghum, and grain sorghum. Perennial WSGs reduced

26 wind erodible fraction by 1.08 to 1.16 times compared with row crops. The geometric mean

27 diameter of dry aggregates under switchgrass and miscanthus was 2.8 to 4.5 times greater than

28 under row crops. Dry soil aggregate stability under miscanthus and big bluestem was greater

29 than under row crops. After $5 \mathrm{yr}$, differences in SOC concentration between WSGs and row

30 crops were not statistically significant for the $0-$ to $15-\mathrm{cm}$ depth. Photoperiod sensitive and sweet

31 sorghum had greater biomass yield than WSGs. In 2011, miscanthus yielded more biomass than

32 corn by $5.3 \mathrm{Mg} \mathrm{ha}^{-1}$. Overall, growing dedicated bioenergy crops can reduce the soil's

33 susceptibility to wind erosion but may not significantly increase SOC concentration in this

34 region in the short term.

35 Abbreviations: SOC, soil organic carbon; WSGs, warm-season grasses. 
37 Development of environmentally sustainable dedicated energy crops may address concerns about

38 soil and environmental degradation. Dedicated energy crops such as perennial WSGs can be a

39 potential alternative to crop residue removal to provide cellulosic biomass for renewable energy

40 production while improving soil and environmental quality (Blanco-Canqui, 2010). Excessive

41 crop residue removal can adversely affect soil structural stability, SOC pools, water transmission

42 characteristics, soil microbial activity, and other soil properties (Wilhelm et al., 2004; Blanco-

43 Canqui and Lal, 2009). In contrast, perennial WSGs due to their year-round surface cover may

44 protect soil from erosion, improve soil properties, soil productivity, and wildlife habitat and

45 diversity. In addition to their potential as biofuel, perennial WSGs may also serve as a valuable

46 animal feedstock, which is particularly important in years of drought (Craine et al., 2010).

47 In the Great Plains, wind erosion is a major environmental concern. This region witnessed the 48 worst dust storms in United States history during the 1930's (Colacicco et al., 1989). It is well

49 recognized that herbaceous wind barriers can reduce wind erosion, improve crop yield, prevent

50 sandblast damage to crops and trap snow to improve soil moisture (Bilbro and Fryrear, 1988).

51 Similar to wind barriers, plantations of WSGs when grown for forage and biofuel may be an

52 effective management practice to reduce wind erosion. Perennial WSGs provide permanent

53 vegetative cover which can adsorb wind energy, reducing wind velocity (Bilbro and Fryrear,

54 1997). Extensive and deep root systems under perennial WSGs may also stabilize and anchor

55 soil, increasing soil aggregate size and stability. In the Great Plains, wind erosion is usually the

56 greatest between February and May when winds are strong and crops are sparse or not present to

57 protect the soil surface. Presence of dormant WSGs in early spring may reduce wind erosion

58 compared with row crops with limited surface residue cover. Bilbro and Fryrear (1997)

59 concluded that tall and lodge-resistant plants, such as switchgrass, increased the effective 
60 distance of wind barriers. Grasses are able to absorb blowing soil particles and reduce the loss of 61 windblown materials (Bilbro and Fryrear, 1997).

62 Current research on dedicated bioenergy crops mostly focuses on increasing production of

63 biomass (Propheter et al., 2010). As a result, data on dedicated bioenergy crop impacts on soil

64 and water conservation, soil physical properties, SOC dynamics, and other soil and

65 environmental factors are limited, particularly in Kansas. This information is, however, needed

66 to assess the potential benefits of growing dedicated energy crops under different regions.

67 Benefits for WSGs for improving soil properties may be inconsistent, depending on the length of

68 management, grass species, soil type, and climate (Schwartz et al., 2003).

69 Most dedicated bioenergy crops are expected to be grown in marginal lands to reduce

70 concerns over competition for land with prime agricultural production (Kort et al., 1997; Cai et

71 al., 2011). Throughout the central Great Plains in general and Kansas in particular, WSGs may

72 fit the dedicated energy crop niche for marginal lands and dryland conditions. Stand

73 establishment and biomass production may determine the feasibility and economic viability of

74 growing perennial WSGs. More research is thus needed to fully understand the capabilities and

75 limitations of growing dedicated energy crops and their impacts on soil and environment in the 76 region.

77 Several recent studies have reported that converting cultivated lands to native WSGs may 78 have the potential to be a C positive system (Liebig et al., 2005). Across the upper Midwest of 79 the USA, Schmer et al. (2011) reported an average SOC increase of 0.5 to $2.4 \mathrm{Mg} \mathrm{ha}^{-1} \mathrm{yr}^{-1}$ under 80 switchgrass grown for biomass production. Across 10 locations in Indiana, Omonode and Vyn

81 (2006) reported that WSGs had greater (22.4 $\left.\mathrm{g} \mathrm{C} \mathrm{kg}^{-1}\right)$ SOC concentration than croplands (19.8 $\mathrm{g}$

$82 \mathrm{C} \mathrm{kg}^{-1}$ ) after 6 to $8 \mathrm{yr}$ of management. Soil organic $\mathrm{C}$ sequestration by WSGs can be greater in 
83 soils with initial low SOC levels. Despite repeated harvest cycles, WSGs such as switchgrass

84 may still increase SOC levels compared with land managed under row crops because of

85 increased belowground biomass input under WSGs (Sanderson, 2008). In the long term,

86 perennial WSGs may also store SOC in deeper soil profile due to their deep and extensive

87 rooting systems (Lemus and Lal, 2005; Follett et al., 2012). More data on the potential of WSGs

88 on increasing SOC concentration are needed for different soils and climatic conditions.

89 Therefore, the objective of this study was to quantify the effects of perennial WSGs and row

90 crops on soil wind erodibility parameters and SOC concentration on a Hapludoll in eastern

91 Kansas. Our study hypothesis was that growing perennial WSGs reduces soil wind erodibility

92 and increases SOC concentration in this soil.

93

MATERIALS AND METHODS

\section{Field Experiment Locations and Treatments}

96 This study was conducted during spring 2011, fall 2011, and spring 2012 on an ongoing

97 bioenergy crop experiment in eastern Kansas established in 2007. The experimental site was

98 located at the Kansas State University’s Agronomy Research Farm at Manhattan (39¹1 'N,

$\left.9996^{\circ} 35^{\prime} \mathrm{W}\right), \mathrm{KS}$. Mean annual precipitation for the site is $838 \mathrm{~mm}$. The soil is a Kahola silt loam

100 (fine-silty, mixed, super active, mesic Cumulic Hapludolls) with a slope $<1 \%$. The soil is formed

101 in calcareous silty alluvium, very deep, and located on moderately permeable flood plains. The

102 site is near a stream and is subject to occasional flooding under intense rainstorms. Indeed, in

103 June 2011, a rainfall event produced over $120 \mathrm{~mm}$ of precipitation in a 24-h period, which

104 flooded the study site and redistributed crop residues. This site may be considered as a relatively 
marginal cropland, which might fit the type of land that is being considered for large-scale

106 production of dedicated bioenergy crops.

107 The experiment was a randomized complete block with four replications. The individual plot

108 size was $6.1 \mathrm{~m}$ wide by $10.7 \mathrm{~m}$ long. The experiment consisted of three perennial warm-season

109 grasses ('Kanlow' switchgrass, 'Kaw' big bluestem, and miscanthus), two native grass mixtures

110 [indiangrass (Sorghastrum nutans L.)] /switchgrass/big bluestem mix and a switchgrass/big

111 bluestem mix), continuous corn, corn-soybean, and three sorghum cultivars (photoperiod

112 sensitive, sweet, and grain sorghum) in rotation with soybeans with each rotation phase present

113 each year. For this study on soil properties, seven bioenergy crop treatments including

114 switchgrass, big bluestem, and miscanthus, continuous corn, photoperiod sensitive sorghum,

115 sweet sorghum, and grain sorghum were selected.

116 Detailed information on previous management history and baseline data on soil fertility

117 parameters is reported by Propheter et al. (2010). Furthermore, fertilization, weed control, and

118 other management protocols for both WSGs and row crops, particularly during experiment

119 establishment, is presented by Propheter and Staggenborg (2010). Briefly, switchgrass and big

120 bluestem were seeded at $4 \mathrm{~kg} \mathrm{ha}^{-1}$ and $6.3 \mathrm{~kg} \mathrm{ha}^{-1}$, respectively, in late spring 2007. Each

121 individual miscanthus plant was hand transplanted in early June 2007 in 1.2 by 1.0 m grid

122 spacing. Weeds were controlled with the use of herbicides, mowing, and hand weeding in 2007

123 and 2008. Once WSGs were established, no weed control was necessary.

124 In 2007, miscanthus was fertilized at transplanting, but switchgrass and big bluestem were not

125 fertilized to reduce weed pressure. Each miscanthus plant was fertilized with $10.5 \mathrm{~g}$ of Miracle-

126 Gro (24-8-16). To correct for the low $\mathrm{P}$ and $\mathrm{K}$ soil test levels, $151 \mathrm{~kg} \mathrm{P}_{2} \mathrm{O}_{5} \mathrm{ha}^{-1}$ as triple super

127 phosphate $(0-46-0)$ and $336 \mathrm{~kg} \mathrm{~K}_{2} \mathrm{O} \mathrm{ha}^{-1}$ as potash (0-60-0) was applied in 2008. All plots 
128 under WSGs received $45 \mathrm{~kg} \mathrm{~N} \mathrm{ha}^{-1}$ as urea (46-0-0) from 2008 to 2012. All row crops were

129 planted in spring with a no-till planter on $0.76 \mathrm{~m}$ row spacing. Urea was surface applied to row

130 crops at about $180 \mathrm{~kg} \mathrm{~N} \mathrm{ha}^{-1}$ from 2007 to 2012 . Weeds in annual row crops were controlled

131 with atrazine [6-chloro-N-ethyl-N'-(1-methylethyl)-1,3,5-triazine-2,4-diamine] and S-

132 metolachlor (2-Chloro-N-(2-ethyl-6-methylphenyl)-N-[(1S)-2-methoxy-1-

133 methylethyl]acetamide; Propheter et al., 2010; Propheter and Staggenborg, 2010).

\section{Measurement of Soil Properties}

136 Soil attributes including aggregate size distribution, aggregate stability, wind erodible fraction,

137 and geometric mean diameter of dry aggregates were used as parameters to evaluate the soil's

138 susceptibility to wind erosion (Skidmore et al., 1990). Aggregate size distribution and aggregate

139 stability were measured, while wind erodible fraction and aggregate geometric mean diameter

140 were computed from aggregate size distribution data. Soil samples were collected at three

141 different times (spring 2011, fall 2011, and spring 2012) to study how differences in biomass

142 cover and precipitation input affected soil response to bioenergy crops. Soil samples for all

143 analysis were collected in March (at the beginning the growing season of WSGs) in 2011 and

1442012 and November (after harvest) in fall 2011.

145 Approximately, $4 \mathrm{~kg}$ of soil were sampled using a flat shovel for the 0 to $5 \mathrm{~cm}$ soil depth in 146 each plot. Soil was carefully sampled to ensure that samples included intact aggregates. The 147 samples were placed into collection pans, transported to the laboratory, and oven-dried at $60^{\circ} \mathrm{C}$ 148 for 2 days. The oven-dry samples were then sieved using a rotary sieve apparatus (Chepil, 1962;

149 Lyles et al., 1970). Sieve size fractions were: <0.42, 0.42-0.84, 0.84-2.0, 2.0-6.35, 6.35-14.05,

$150 \quad 14.05-44.45$ and $>44.45 \mathrm{~mm}$. Aggregates from each sieve were weighed to determine the mass of 
151 aggregates for each size fraction. The wind erodible fraction was computed as the mass of $<0.84$

$152 \mathrm{~mm}$ aggregates divided by the total mass of aggregates in different size fractions. The geometric

153 mean diameter of dry aggregates using the mass of aggregates and aggregate size fractions was

154 computed (Nimmo and Perkins, 2002).

155 Separate soil samples were collected for the determination of the dry stability of individual

156 aggregates. Samples were collected using a flat shovel for a $5 \mathrm{~cm}$ soil depth and passed through a

$15719.0 \mathrm{~mm}$ diameter sieve in the field. The sieved samples were then air-dried for $72 \mathrm{~h}$. A

158 subsample of 30 aggregates were selected from each air-dry sample and were finger manipulated

159 to obtain an approximate spherical shape. Each aggregate was then individually crushed using a

160 crushing meter. The aggregate crushing-meter apparatus consisted of two parallel plates

161 supported by a load cell, which was connected to a computer to measure the crushing energy of

162 the aggregate (Boyd et al., 1983). Dry aggregate stability was expressed as the natural log of the

163 crushing energy per unit mass (Skidmore and Powers. 1982; Layton et al., 1993). In this paper,

164 the term dry aggregate stability is used to indicate the crushing strength of dry aggregates as

165 defined by Skidmore and Powers (1982).

166 Total $\mathrm{C}$ and $\mathrm{N}$ concentrations were determined in bulk samples collected in spring 2012 for

167 the 0 - to 7.5 - and 7.5- to 15.0 -cm depth. The samples were air-dried for $72 \mathrm{~h}$,ground in a roller

168 mill, and pass through a $0.25 \mathrm{~mm}$ sieve. Total $\mathrm{C}$ and $\mathrm{N}$ concentration in the ground sample was

169 analyzed by dry combustion using a LECO TruSpecCN analyzer (LECO Corp., St. Joseph, MI).

170 Because the soil $\mathrm{pH}$ in the study plots was $<7$ (Propheter and Staggenborg, 2010), SOC was

171 considered equivalent to total $\mathrm{C}$ for discussion purposes.

172

173 
175 Harvesting protocols and determination of dry biomass for both WSGs and row crops are also

176 described by Propheter et al. (2010) and Propheter and Staggenborg (2010). Briefly, WSGs were

177 harvested after the first killing frost in November using a walk-behind sickle mower. Biomass

178 yields were determined by harvesting the center $1.2 \mathrm{~m}$ by $10.7 \mathrm{~m}$ area of the plot. Harvested

179 biomass was then hand raked, collected, and weighed. A sample from the harvested biomass was 180 dried at $65^{\circ} \mathrm{C}$ for $240 \mathrm{~h}$ for dry biomass yield. Average stubble height of WSGs after harvest was

181 about $10 \mathrm{~cm}$. Row crops were harvested at physiological maturity in September and October. A

182 4.6-m length from each of the center two rows was harvested to a stubble height of $10 \mathrm{~cm}$. A

183 biomass subsample was weighed, dried at $65^{\circ} \mathrm{C}$ for $240 \mathrm{~h}$, and weighed again to calculate dry

184 biomass yield. After sampling, WSG and row crop biomass remaining in each plot was removed 185 from the plots after harvest.

\section{Statistical Analysis}

187 Data were statistically analyzed using PROC Mixed in SAS 9.2 (SAS Institute, 2012).

188 Significance of main effect differences was determined with species as the fixed effect and 189 replication as the random effect. Least square differences were used to determine differences in 190 soil properties and biomass yields at the 0.05 probability levels (SAS Institute, 2012). Treatment 191 effects were evaluated at the 0.05 probability level.

\section{RESULTS}

\section{Wind Erodible Fraction and Aggregate Size}

194 Perennial WSGs (switchgrass, miscanthus, and big bluestem) had large and significant effects 195 on wind erodible fraction and geometric mean diameter of dry aggregates relative to row crops 196 including continuous corn, photoperiod sorghum, sweet sorghum, and grain sorghum. In spring 
1972011 (4 yr after experiment establishment), switchgrass and miscanthus reduced the wind 198 erodible fraction by about 1.08 times compared with row crops (Table 3 ). In this sampling 199 period, wind erodible fraction in big bluestem did not differ from switchgrass, miscanthus, and 200 row crops. In fall 2011, all WSG treatments had lower wind erodible fraction than row crops 201 (Table 3). In this sampling period, wind erodible fraction under WSGs was, on average, 1.10 202 times lower than under row crops except that differences between grain sorghum and miscanthus 203 were not significant. Perennial WSGs had greater effects on reducing wind erodible fraction in 204 spring 2012 than in both spring and fall 2011. On average, WSGs reduced wind erodible fraction 205 by 1.16 times compared with row crops(Table 3 ). There were no differences in the wind 206 erodible fraction among WSGs. While wind erodible fraction among row crops did not differ in 207 2011, sweet sorghum had lower wind erodible fraction than continuous corn in spring 2012 208 (Table 3).

209 Data on the geometric mean diameter of dry aggregates displayed trends similar to the wind 210 erodible fraction data. In spring 2011, geometric mean diameter in switchgrass and miscanthus 211 was, on average, 3.5 times greater than in row crops (Table 3). However, differences between 212 big bluestem and row crops were not significant. In fall 2011, switchgrass and miscanthus had 213 about 4.6 times greater geometric mean diameter than row crops except grain sorghum, which 214 did not differ from miscanthus and big bluestem (Table 3). In spring 2012, magnitude of 215 differences in geometric mean diameter between WSGs and row crops appeared to be smaller 216 than in 2011, but WSGs had consistently greater geometric mean diameter than row crops (Table

217 3). Geometric mean diameter of aggregates in WSGs was 2.8 times greater than in row crops

218 (Table 3). At all sampling times, differences in geometric mean diameter of dry aggregates 219 among row crops were not significant (Table 3). 
221 Perennial WSGs appeared to have less consistent effects on dry aggregate stability than on

222 the wind erodible fraction and geometric mean diameter of dry aggregates, but differences were

223 significant (Table 3). In spring 2011, miscanthus had the highest dry aggregate stability (4.12 ln J

$224 \mathrm{~kg}^{-1}$ ) of all treatments (Table 3). Both miscanthus and switchgrass had about 1.1 times greater

225 dry aggregate stability than row crops in spring 2011. Big bluestem had also greater aggregate

226 stability but only when compared with continuous corn and sweet sorghum. In fall 2011,

227 switchgrass and big bluestem had about 1.2 times greater aggregate stability than sweet sorghum 228 and grain sorghum but had similar values to the other two row crops. In spring 2012, miscanthus

229 and big bluestem had 1.2 times greater aggregate stability than row crops and switchgrass.

230 Unlike in spring and fall 2011, soil aggregate stability in switchgrass did not differ from that in

231 row crops in spring 2012. Soil aggregate stability among row crops did not differ at any

232 sampling date (Table 3)

\section{Soil Organic Carbon and Nitrogen and Biomass Yield}

234 Differences in SOC and N concentrations among treatments were not significant (Table 1). In 235 the 0 - to 7.5-cm depth, mean SOC averaged across switchgrass and miscanthus was $15.5 \mathrm{~g} \mathrm{~kg}^{-1}$,

236 while the mean SOC across row crops was only $13.6 \mathrm{~g} \mathrm{~kg}^{-1}$. Likewise, in the 7.5- to 15 -cm depth,

237 mean SOC averaged across switchgrass and miscanthus was $14.8 \mathrm{~g} \mathrm{~kg}^{-1}$, and that for row crops

238 was $11.8 \mathrm{~g} \mathrm{~kg}^{-1}$. While there were no statistical differences, the magnitude of differences in mean

239 SOC between WSGs (switchgrass and miscanthus) and row crops appeared to be lower in the 0-

240 to $7.5-\mathrm{cm}$ depth $\left(1.9 \mathrm{~g} \mathrm{~kg}^{-1}\right)$ than in the 7.5 - to $15-\mathrm{cm}$ depth $\left(3 \mathrm{~g} \mathrm{~kg}^{-1}\right.$; Table 1$)$, suggesting that

241 WSGs may increase SOC concentration with depth in the long term. 
There were significant differences in total biomass yields among the treatments in both years

243 (Table 2). In 2010, photoperiod sensitive, sweet sorghum, and grain sorghum had greater

244 biomass yield than WSGs, but, in 2011, only photoperiod sensitive and sweet sorghum had

245 greater biomass yield than WSGs (Table 2). Biomass yield between continuous corn and WSGs

246 did not differ in both years. In 2011, miscanthus had greater biomass yield than continuous corn

247 by $5.3 \mathrm{Mg} \mathrm{ha}^{-1}$. Unlike in 2010, biomass yield from WSGs did not differ from grain sorghum

248 biomass yields. Also, photoperiod sensitive and sweet sorghum varieties had greater biomass

249 yields than continuous corn and grain sorghum in both 2010 and 2011.

\section{DISCUSSION}

251 Data on soil wind erodibility showed that perennial WSGs can reduce soil's susceptibility to

252 wind erosion and improve soil structural properties. Soils under WSGs, particularly miscanthus

253 and switchgrass, had a greater fraction of large aggregates than soils managed under

254 conventional cropping systems. Dry soil aggregates under WSGs were also more stable, less

255 likely to abrade into small aggregates, and thus were less susceptible to wind erosion than those

256 under row crops. The reduced wind erodible fraction, increased aggregate size, and improved

257 aggregate stability in soils under WSGs could be attributed to the increased continuous uniform

258 surface cover and extensive root system under WSGs relative to row crops (Table 3). The

259 consistently lower wind erodible fraction and greater size of soil dry aggregates under WSGs

260 than in row crops during both fall and spring sampling indicates that WSGs were effective at

261 reducing soil erodibility across all seasons. Perennial WSGs probably maintained a permanent

262 and effective soil cover even during winter, reducing effects of soil freezing-thawing cycles

263 unlike under row crops. The stubble under WSGs was cut at $10 \mathrm{~cm}$ height during harvest, which

264 left a significant amount of soil cover during winter. The smaller positive effects of big bluestem 
265 than miscanthus and switchgrass may be due to the lower biomass yield and slow establishment 266 of this grass species in this climate.

267 The lack of significant differences in SOC concentration between WSGs and row crops after 5 268 yr of management was somewhat surprising, but not unexpected considering the short-term 269 management of WSGs in this study. The lack of differences in SOC concentration among WSGs 270 and continuous corn and grain sorghum is probably explained by the lack of differences in 271 biomass yields. However, it is important to note that photoperiod and sweet sorghum row crops 272 did not increase SOC concentration relative to WSGs in spite of producing higher amount of 273 biomass than WSGs. On average, photoperiod and sweet sorghum (20.1 $\left.\mathrm{Mg} \mathrm{ha}^{-1}\right)$ produced 274 about 1.7 times more biomass than WSGs (11.8 $\mathrm{Mg} \mathrm{ha}^{-1}$; Table 2). Because biomass was 275 removed at maturity from all treatments, the lack of effect of photoperiod and sweet sorghum on 276 SOC suggests that the belowground biomass production among photoperiod and sweet sorghum 277 and WSGs did not differ. Perennial WSGs may have greater root biomass in deeper soil profile 278 than row crops in the long term (Zan et al., 1997).

279 Results suggest that bioenergy crops may not rapidly increase SOC concentration in all soils, 280 particularly in the short term. Similar studies have reported that potential of WSGs for increasing 281 SOC can be site-specific. In Indiana, after 6 to 8 yr of management, SOC concentration in warm282 season native grasses $\left(22.4 \mathrm{~g} \mathrm{~kg}^{-1}\right)$ was higher than in corn-soybean $\left(19.8 \mathrm{~g} \mathrm{~kg}^{-1}\right)$ only in 4 out of 28310 paired fields for the 0 - to 15 -cm soil depth (Omonode and Vyn, 2006). . Although differences 284 in mean SOC concentration under WSGs (switchgrass and miscanthus) were numerically larger 285 than mean SOC concentration across row crops for both soil depth intervals, these differences 286 were not statistically significant due in part, to the high variability in SOC data among 
287 replications. We hypothesize, however, that WSGs will increase SOC concentration relative to 288 row crops in the long term as WSGs mature.

289 Our results on biomass yield support those reported for the same experiment for the 2007 and 2902008 growing seasons by Propheter et al. (2010) who found that total biomass yield was the 291 greatest for sweet sorghum. They also noted that biomass yields of perennial WSG significantly 292 increased between 2007 and 2008, which suggests that WSG biomass production may continue 293 to increase with time and may prove to be competitive with row crops in the long term. The 294 lower WSGs biomass yield in 2010 compared with grain sorghum with no differences in 2011 295 (Table 2) can be attributed to an observed yield increase under perennial WSGs from 2010 to 2962011 combined with a grain sorghum yield decline due to limited precipitation. The increased 297 yield of the WSGs is likely due to increased stand maturity in addition, possibly, to the grasses 298 ability to utilize stored profile water after winter and early season precipitation events.

299 It is important to note the variability of the wind erodibility parameters observed among the 300 three sampling dates (Table 3). Variations in dry soil aggregate properties from year to year or 301 even from season to season is not uncommon in this climate. Across 10 soils in Kansas, 302 Skidmore and Layton (1992) observed a large variation in dry aggregate stability from year to 303 year in silt loams. Similarly, in west central Kansas, Layton et al. (1993) found that soil wind 304 erodibility parameters including size, stability, and density of dry aggregates varied between 305 years and between fall and winter under different tillage (conventional till, reduce till, and no306 till) and surface cover management scenarios. Dynamic dry aggregate properties can vary from 307 season to season in response to differences in precipitation input and soil temperature, residue 308 input, which can directly affect freezing and thawing, and wetting and drying cycles (Layton et 309 al., 1993). Our results confirm the importance of monitoring changes in soil aggregate properties 
310 at different times under dedicated bioenergy crops to better understand the temporal changes in

311 soil wind erodibility properties.

\section{CONCLUSIONS}

314 This study in eastern Kansas indicates that dedicated bioenergy crops such as perennial WSGs

315 including switchgrass, big bluestem, and miscanthus reduce the soil's susceptibility to wind

316 erosion relative to annual row crops. The significant reduction in wind erodible fraction and

317 increase in dry aggregate size and stability under WSGs suggests that WSGs can improve soil

318 structural quality compared with row crops. The beneficial effects of WSGs on reducing soil

319 wind erodibility may be particularly important in agriculturally marginal lands. Results suggest

320 that perennial WSGs grown for biofuel or livestock may improve soil and environmental quality

321 in this region. Results also indicate that the potential of WSGs for increasing SOC concentration

322 may be limited in the short term. Further research is needed to determine long-term soil benefits

323 and identify the most appropriate WSG species in this climate. Overall, this study in eastern

324 Kansas indicated that, in the short term, dedicated bioenergy crops can have more beneficial

325 impacts on reducing risks of soil erosion than on increasing SOC concentration or biomass yields

326 compared with row crops. Further research is needed to assess long-term impacts on soil

327 functions and develop sustainable dedicated bioenergy crop systems in the region. 
331 Bilbro J. D., and D.W. Fryrear. 1988. Annual herbaceous wind barriers for protecting crops and 332 soils managing snowfall. Agric. Ecosyst. Environ. 22/23:149-161.

333 Bilbro J. D., and D.W. Fryrear. 1997. Comparative performance of forage sorghum, grain 334 sorghum, kenaf, switchgrass, and slat-fence wind barriers in reducing wind velocity. J. Soil $335 \quad$ Water Conserv. 52:447-452.

336 Blanco-Canqui, H. 2010. Energy crops and their implications on soil and environment. Agron. J. $337 \quad 102: 403-419$.

338 Blanco-Canqui, H., and R. Lal. 2009. Crop residue removal effects on soil, productivity and 339 environmental quality. Crit. Rev. Plant Sci. 28:139-163.

340 Boyd, D.W., E.L. Skidmore, and J.G. Thompson. 1983. A soil-aggregate crushing-energy meter. $341 \quad$ Soil Sci. Soc. Am. J. 47:313-316.

342 Cai, X., X. Zhang, and D. Wang. 2011. Land availability for biofuel production. Environ. Sci. 343 Technol. 45:334-339.

344 Chepil, W.S. 1962. Improved rotary sieve for measuring state and stability of dry soil structure. 345 Soil Sci. Soc. Am. Proc. 26:4-6.

346 Colacicco, D., T. Osborn, and K. Alt. 1989. Economic damage from soil erosion. J. Soil Water 347 Conserv. 44:35-39.

348 Craine, J.M., A.J. Elmore, K.C. Olson, and D. Tollenson. 2010. Climate change and cattle 349 nutritional stress. Global Change Biol. 16:2901-2911.

350 Follett, R.F., K.P. Vogel, G.E. Varvel, R.B. Mitchell, and J. Kimble. 2012. Soil carbon 351 sequestration by switchgrass and no-till maize grown for bioenergy. Bioenergy Res. 5:866352875. 
353 Kort, J., M. Collins, and D. Ditsch. 1997. A review of soil erosion potential associated with $354 \quad$ biomass crops. Biomass Bioenergy 14:351-359.

355 Layton, J.B., E.L. Skidmore, and C.A. Thompson. 1993. Winter-associated changes in dry-soil 356 aggregation as influenced by management. Soil Sci. Soc. Am. J. 57:1568-1572.

357 Lemus, R., and R. Lal. 2005. Bioenergy crops and carbon sequestration. Crit. Rev. Plant Sci. $358 \quad 24: 1-21$.

359 Liebig, M.A., H.A. Johnson, J.D. Hanson, and A.B. Frank. 2005. Soil carbon under switchgrass 360 stands and cultivated cropland. Biomass Bioenergy 28:347-354.

361 Lyles, L., J.D. Dickerson, and L.A. Disrud. 1970. Modified rotary sieve for improved accuracy. 362 Soil Sci. 109:207-210.

363 Nimmo, J.R., and K.S. Perkins. 2002. Aggregate stability and size distribution. p. 317-327. In

364 J.H. Dane and G. C. Topp (ed.) Methods of soil analysis. Part 4. SSSA Book Ser. 5. SSSA, 365 Madison, WI.

366 Omonode, R.A., and T.J. Vyn. 2006. Vertical distribution of soil organic carbon and nitrogen 367 under warm-season native grasses relative to cropland in west-central Indiana, USA. Agric. 368 Ecosyst. Environ. 117:159-170.

369 Propheter, J.L., S.A. Staggenborg, X. Wu, and D. Wang. 2010. Performance of annual and 370 perennial biofuel crops: Yield during the first two years. Agron. J. 102:806-814.

371 Propheter, J.L., and S.A. Staggenborg. 2010. Performance of annual and perennial biofuel crops: 372 Nutrient removal during the first two years. Agron. J. 102:798-805.

373 Sanderson, M.A. 2008. Upland switchgrass yield, nutritive value, and soil carbon changes under 374 grazing and clipping. Agron. J. 100:510-516. 
375 Schmer, M.R., M.A. Liebig, K.P. Vogel, and R.B. Mitchell. 2011. Field-scale soil property

376 changes under switchgrass managed for bioenergy. Global Change Biol. Bioenergy 3:439-

$377 \quad 448$.

378 SAS Institute. 2012. SAS Online Doc 9.1.3. Available at

379 support.sas.com/onlinedoc/913/docMainpage.jsp (verified July, 2012). SAS Institute Inc., 380 Cary, NC.

381 Schwartz, R.C., S.R. Evett, and P.W. Unger. 2003. Soil hydraulic properties of cropland

382 compared with reestablished and native grassland. Geoderma 116:47-60.

383 Skidmore, E.L. and J.B. Layton. 1992. Dry-aggregate stability as influenced by selected soil

384 properties. Soil Sci. Soc. Am. J. 56:557-561.

385 Skidmore, E.L., L.J. Hagen, D.V. Armbrust, A.A. Durar, D.W. Fryrear, K.N. Potter, L.E.

386 Wagner, and T.M. Zobeck. 1990. Methods for investigating basic processes and conditions

387 affecting wind erosion. p. 295-330. In R. Lal (ed.) Soil Erosion Research Methods. Soil Water

388 Conserv. Soc., Ankeny, IA.

389 Skidmore, E.L. and D.H. Powers. 1982. Dry soil-aggregate stability: Energy-based index. Soil

390 Sci. Soc. Am. J. 46:1274-1279.

391 Wilhelm, W.W., J.M.F. Johnson, J.L. Hatfield, W.B. Voorhees, and D.R. Linden. 2004. Crop

392 and soil productivity response to corn stover removal: A literature review. Agron. J. 96:1-17.

393 Zan, C., J. Fyles, P. Girouard, R. Samson, and M. Doan. 1997. Carbon storage in switchgrass and

394 short-rotation willow plantations. p. 355-361. In R.P. Overend and E. Chornet (ed.) Making a

395 business from biomass in energy, environment, chemicals, fibers, and materials. Vol. 1.

396 Elsevier Science, Oxford, UK. 
Table 1. Impacts of dedicated bioenergy crops and annual row crops on soil nitrogen and carbon concentration for samples collected for two soil depths in spring 2012. Treatment effects were not significant at the $\mathrm{p}<0.05$ level.

\begin{tabular}{lccccc}
\hline Treatment & $\begin{array}{c}\text { Tepth } \\
(\mathrm{cm})\end{array}$ & $\begin{array}{c}\text { Total } \\
\text { Nitrogen } \\
\left(\mathrm{g} \mathrm{kg}^{-1}\right)\end{array}$ & $\begin{array}{c}\text { Standard } \\
\text { Deviation } \\
( \pm)\end{array}$ & $\begin{array}{c}\text { Total } \\
\text { Carbon } \\
\left(\mathrm{g} \mathrm{kg}^{-1}\right)\end{array}$ & $\begin{array}{c}\text { Standard } \\
\text { Deviation } \\
( \pm)\end{array}$ \\
\hline Continuous corn & & & & & \\
Photoperiod sorghum & 7.5 & 1.2 & 0.11 & 13.3 & 2.0 \\
Sweet sorghum & 7.5 & 1.3 & 0.31 & 14.9 & 3.8 \\
Grain sorghum & 7.5 & 1.2 & 0.25 & 13.0 & 3.2 \\
Miscanthus & 7.5 & 1.2 & 0.18 & 13.2 & 1.9 \\
Switchgrass & 7.5 & 1.3 & 0.24 & 14.7 & 2.8 \\
Big bluestem & 7.5 & 1.4 & 0.50 & 16.4 & 5.0 \\
& 7.5 & 1.1 & 0.13 & 12.2 & 1.8 \\
Continuous corn & & & & & \\
Photoperiod sorghum & 15 & 1.0 & 0.21 & 11.8 & 2.2 \\
Sweet sorghum & 15 & 1.1 & 0.19 & 11.6 & 2.4 \\
Grain sorghum & 15 & 1.1 & 0.21 & 11.9 & 2.2 \\
Miscanthus & 15 & 1.1 & 0.21 & 11.9 & 2.3 \\
Switchgrass & 15 & 1.2 & 0.30 & 13.9 & 3.3 \\
Big bluestem & 15 & 1.4 & 0.41 & 15.7 & 4.1 \\
\hline
\end{tabular}


Table 2. Total biomass dry matter yields for dedicated bioenergy crops and annual row crops in 2010 and 2011. Different letters indicate significant differences at the $\mathrm{p}<0.05$ level.

\begin{tabular}{lrr}
\hline \multirow{2}{*}{ Treatment } & \multicolumn{2}{c}{ Biomass Yield } \\
\cline { 2 - 3 } & \multicolumn{2}{c}{$\frac{\mathrm{Mg} \mathrm{ha}^{-1}}{}$} \\
\hline Continuous Corn & $7.26 \mathrm{c}$ & $8.46 \mathrm{c}$ \\
Photo Period Sorghum & $20.77 \mathrm{a}$ & $20.77 \mathrm{a}$ \\
Sweet Sorghum & $23.19 \mathrm{a}$ & $19.44 \mathrm{a}$ \\
Grain Sorghum & $13.8 \mathrm{~b}$ & $11.57 \mathrm{bc}$ \\
Big Bluestem & $3.79 \mathrm{~d}$ & $10.93 \mathrm{bc}$ \\
Miscanthus & $9.69 \mathrm{c}$ & $13.78 \mathrm{~b}$ \\
Switchgrass & $7.9 \mathrm{c}$ & $10.89 \mathrm{bc}$ \\
\hline
\end{tabular}


Table 3. Impacts of dedicated bioenergy crops and annual row crops on wind erodible fraction ( $<0.84 \mathrm{~mm}$ dry aggregates), geometric mean diameter of dry aggregates, and aggregate stability. Columns followed by the same letter within a sampling period and soil property are not significantly different at the $\mathrm{p}<0.05$ level.

\begin{tabular}{|c|c|c|c|}
\hline Treatment & $\begin{array}{l}\text { Wind Erodible } \\
\text { Fraction } \\
(\%)\end{array}$ & $\begin{array}{l}\text { Geometric Mean } \\
\text { Diameter } \\
(\mathrm{mm})\end{array}$ & $\begin{array}{l}\text { Aggregate } \\
\text { Stability } \\
\left(\ln \mathrm{J} \mathrm{kg}^{-1}\right)\end{array}$ \\
\hline
\end{tabular}

Spring 2011

$\begin{array}{lccc}\text { Continuous Corn } & 16.7 \mathrm{a} & 9.1 \mathrm{~b} & 3.2 \mathrm{~d} \\ \text { Photo Period Sorghum } & 18.6 \mathrm{a} & 10.2 \mathrm{~b} & 3.3 \mathrm{~cd} \\ \text { Sweet Sorghum } & 19 \mathrm{a} & 8.1 \mathrm{~b} & 3.1 \mathrm{~d} \\ \text { Grain Sorghum } & 18.9 \mathrm{a} & 6.8 \mathrm{~b} & 3.3 \mathrm{~cd} \\ \text { Miscanthus } & 6.9 \mathrm{~b} & 28.6 \mathrm{a} & 4.1 \mathrm{a} \\ \text { Switchgrass } & 7.9 \mathrm{~b} & 31.7 \mathrm{a} & 3.7 \mathrm{~b} \\ \text { Big Bluestem } & 15.4 \mathrm{ab} & 15 \mathrm{ab} & 3.6 \mathrm{bc}\end{array}$

$\underline{\text { Fall } 2011}$

Continuous Corn

Photo Period Sorghum

Sweet Sorghum

Grain Sorghum

Miscanthus

Switchgrass

Big Bluestem

Continuous Corn

Photoperiod Sorghum

Sweet Sorghum

Grain Sorghum

Miscanthus

Switchgrass

Big Bluestem
$25.6 \mathrm{a}$

$24.9 \mathrm{a}$

26.3a

23. $4 \mathrm{ab}$

$13.2 \mathrm{bc}$

$6.6 \mathrm{c}$

$10.9 \mathrm{c}$

43.1a

$34.8 \mathrm{ab}$

$31.7 \mathrm{~b}$

$33.9 \mathrm{ab}$

$13.6 \mathrm{c}$

$17.0 \mathrm{c}$

$16.7 \mathrm{c}$
$4.0 \mathrm{c}$

$3.6 \mathrm{c}$

$3.4 \mathrm{c}$

$4.9 \mathrm{bc}$

13.3ab

21,0a

$11.9 \mathrm{bc}$

Spring 2012

\section{$1.2 \mathrm{c}$}

$2.3 \mathrm{c}$

$3.2 b$

$2.6 \mathrm{bc}$

$3.2 \mathrm{~b}$

$2.6 \mathrm{bc}$

$3.1 \mathrm{~b}$

6.0ab

$4.1 \mathrm{a}$

$6.6 \mathrm{a}$

$3.3 \mathrm{~b}$

$5.8 \mathrm{abc}$

$3.9 \mathrm{~b}$ 